\title{
Penanganan Diversi Anak sebagai Tersangka dalam Tindak Pidana Pencurian Kenderaan Bermotor pada Polres Sibolga
}

\section{Handling Diversion of Children as Suspects in The Crime of Motor Vehicle Theft at The Sibolga Police}

\author{
Suprihanto Pardjanihadi1), Ediwarman2) \& Rizkan Zulyadi1)* \\ 1) Program Magister Ilmu Hukum, Universitas Medan Area, Indonesia \\ 2) Program Magister Ilmu Hukum, Universitas Sumatera Utara Area, Indonesia
}

Diterima: 06 Agustus 2021; Direview: 06 Agustus 2021; Disetujui: 07 Oktober 2021

*Coresponding Email: rizkanzulyadi@staff.uma.ac.id

\begin{abstract}
Abstrak
Tujuan penelitian adalah menganalisis aturan hukum dalam penerapan diversi terhadap anak; faktor penyebab terjadinya tindak pidana pencurian kenderaan bermotor oleh anak dan kebijakan diversi terhadap tersangka anak dalam tindak pidana pencurian kenderaan bermotor pada Kepolisian Resor Sibolga. Metode penelitian yang digunakan adalah metode deskriptif, sedangkan teknik analisis data menggunakan deskriptif kualitatif. Hasil penelitian menunjukkan bahwa Aturan hukum dalam penerapan diversi terhadap anak yang melakukan tindak pidana yang diatur pada Undang-undang No.11 Tahun 2012 tentang Sistem Peradilan Pidana Anak, yaitu pada pasal 6 - pasal 15 dan Undang-undang No. 35 Tahun 2014 Tentang Perlindungan Anak, yaitu pasal 1 angka (2). Faktor penyebab terjadinya pencurian adalah dari faktor intern yaitu faktor ekonomi dimana anak berasal dari keluarga golongan ekonomi lemah, kurangnya pengawasan orang tua karena sibuk dalam pekerjaan, kurangnya kesadaran hukum oleh anak karena masih kurang matang dalam berpikir, kebutuhan narkotika karena sudah salah dalam pergaulan teman, faktor ekstern faktor adanya kesempatan melakukan pencurian, adanya pengaruh lingkungan dimana anak terhubung dengan kelompok kriminal ataupun geng motor, adanya pengaruh orang dewasa yang berupaya memanfaatkan anak-anak untuk melakukan pencurian kenderaan bermotor, dan banyaknya penadah kenderaan bermotor hasil curian. Kebijakan diversi terhadap tersangka anak dalam tindak pidana pencurian kenderaan bermotor pada Kepolisian Resor Sibolga dilakukan dengan cara kebijakan formal dan non formal Kata Kunci: Penanganan; Diversi; Anak; Tersangka; Tindak Pidana Pencurian Kenderaan Bermotor.
\end{abstract}

\begin{abstract}
The research objective is to analyze the rule of law in the application of diversion to children; the factors causing the criminal act of theft of motorized vehicles by children and the diversion policy against child suspects in the crime of theft of motorized vehicles at the Sibolga Resort Police. The research method used is descriptive method, while the data analysis technique uses descriptive qualitative. The results of the study indicate that the rule of law in the application of diversion to children who commit criminal acts is regulated in Law No. 11 of 2012 concerning the Juvenile Criminal Justice System, namely in articles $6-15$ and Law no. 35 of 2014 concerning Child Protection, namely article 1 number (2). Factors causing the theft are internal factors, namely economic factors where children come from families of weak economic groups, lack of parental supervision because they are busy at work, lack of legal awareness by children because they are still not mature in thinking, narcotics needs because they are wrong in the association of friends, external factors are the opportunity to commit theft, the influence of the environment where children are connected to criminal groups or motorcycle gangs, the influence of adults who try to take advantage of children to commit theft of motorized vehicles, and the number of collectors of stolen motorized vehicles. The diversion policy against child suspects in the crime of motor vehicle theft at the Sibolga Resort Police is carried out by means of formal and non-formal policies. Keywords: Handling; Diversion; Child; Suspect; Motor Vehicle Theft.
\end{abstract}

How to Cite: Pardjanihadi, S., Ediwarman, E., \& Zulyadi, R. (2021). Penanganan Diversi Anak sebagai Tersangka dalam Tindak Pidana Pencurian Kenderaan Bermotor pada Polres Sibolga. Journal of Education, Humaniora and Social Sciences (JEHSS).4(2):1222-1233. 


\section{PENDAHULUAN}

Perhatian terhadap perkembangan anak sejak saat usia dini sangat diperlukan mengingat bahwa masa kanak-kanak merupakan periode pembentukan watak dan kepribadian diri seorang manusia, yang nantinya akan mempengaruhi kemampuan anak kelak setelah dewasa (Prints, 2002). Oleh karena itu semua pihak khususnya pemerintah dan orang tua anak harus berupaya menjamin perlindungan terhadap anak, agar dapat menjamin terpenuhinya hak-hak anak untuk hidup, tumbuh, berkembang, dan berpartisipasi secara optimal sesuai dengan harkat dan martabat kemanusiaan, serta mendapat perlindungan dari kekerasan dan diskriminasi, demi terwujudnya anak Indonesia yang berkualitas, berakhlak mulia, dan sejahtera. Adapun hak-hak anak yang perlu mendapat perlindungan hukum adalah terhindari dari diskriminasi, eksploitasi, baik ekonomi maupun seksual, penelantaran, kekejaman, kekerasan, penganiayaan, ketidakadilan, dan perlakuan salah lainnya (Gultom, 2012). Selain itu, pada pasal 2 ayat (4) UU Perlindungan Anak juga telah dinyatakan bahwa: Anak berhak atas perlindungan terhadap lingkungan hidup yang dapat membahayakan atau menghambat pertumbuhan dan perkembangannya dengan wajar.

Salah satu kondisi yang dapat menghambat pertumbuhan anak adalah konflik dengan hukum oleh anak yang melakukan tindak pidana. Konflik dengan hukum dapat menghambat perkembangan anak jika kebebasannya dirampas dan mengalami perlakuan tidak manusiawi selama anak menjalani proses peradilan pidana (Djamil, 2012). Oleh karena itu pemerintah telah menetapkan Undang-undang No. 11 Tahun 2012 tentang Sistem Peradilan Pidana Anak (UU SPPA), yang tujuan utamanya adalah untuk menjaga harkat dan martabat anak dengan memberikan perlindungan hukum dalam sistem peradilan, yang disertai dengan pemberian kesempatan seluas-luasnya untuk menyelesaikan perkara di luar pengadilan melalui diversi.

Diversi adalah pengalihan penyelesaian perkara anak dari proses pengadilan pidana ke proses di luar pengadilan pidana. Inti dari diversi adalah penyelesaian perkara anak melalui musyawarah di luar pengadilan yang difasilitasi oleh aparat penegak hukum, agar anak dapat terhindar dari proses peradilan pidana dan terhindar dari perampasan kemerdekaan. Namun demikian keberhasilan diversi membutuhkan membutuhkan keterlibatan dan keseriusan semua pihak untuk menghindari agar si anak dapat terbebas dari penjatuhan pidana penjara melalui persidangan di pengadilan (Marlina, 2010).

Perlu disadari bahwa penerapan diversi terhadap anak yang pelaku tindak pidana harus dikedepankan karena pada dasarnya tindakan anak tidaklah sepenuhnya dilakukan dengan penuh kesadaran, karena dianya belum dewasa untuk bertindak, dalam arti belum mampu memahami dengan baik akibat hukum dari segala tindakan yang dilakukan terhadap orang lain (Marlina, 2008). Tindak pidana yang dilakukan oleh anak pada umumnya merupakan proses meniru ataupun terpengaruh bujuk rayu orang dewasa (Gosita, 2003). Proses penghukuman yang diberikan kepada anak melalui sistem peradilan pidana formal dengan memasukkan anak ke dalam penjara ternyata tidak berhasil menjadikan anak menjadi pribadi yang lebih baik untuk menunjang perkembangannya. Oleh karena itu diperlukan sistem hukum yang lebih lunak dalam proses penyelesaian pidana anak, sehingga kepentingan anak tidak dikorbankan oleh sistem hukum yang diberlakukan. Proses penyelesaian pidana anak yang paling lunak tentu adalah penyelesaian melalui diversi.

Berdasarkan UU SPPA, upaya penyelesaian perkara melalui diversi dapat dilakukan pada semua tahapan proses peradilan. Pasal 7 ayat (1) UU No. 11 Tahun 2012 dinyatakan bahwa: pada tingkat penyidikan, penuntutan, dan pemeriksaan perkara anak dipengadilan wajib diupayakan diversi. Dengan demikian dapat diartikan bahwa proses diversi telah dapat diupayakan sejak penyidikan di Kepolisian, dimana penyidik diberi kewenangan untuk melakukan diversi. Dalam hal ini, peranan Kepolisian untuk mengupayakan terjadinya diversi sangat diperlukan, karena pada dasarnya tahapan paling baik untuk melakukan diversi adalah pada tahap penyidikan serta lebih menjamin terhindarnya pelaku anak dari proses peradilan pidana lebih lanjut. Terdapat beberapa hal yang menyebabkan Kepolisian lebih berkompeten dalam pelaksanaan diversi, yaitu: (1) Diversi di tingkat Kepolisian lebih memberikan jaminan kepada anak untuk terhindar dari proses peradilan pidana karena masih dalam perkaranya masih dalam tingkat penyidikan; (2) 
Kepolisian merupakan lembaga penegak hukum yang paling dekat dan bersinggungan langsung dengan masyarakat serta mempunyai jaringan hingga tingkat kecamatan; dan (3) Secara kuantitas, aparat Kepolisian lebih banyak dibanding aparat penegak hukum lainnya walaupun tidak setiap aparat Kepolisian mempunyai kemampuan untuk menangani perkara anak.

Dari uraian di atas jelaslah bahwa peranan Kepolisian dalam upaya penerapan diversi adalah sangat penting terutama karena jaringannya sangat luas dan bersinggungan secara langsung dengan kehidupan masyarakat. Artinya, aparat Kepolisian lebih mampu mengetahui dan memahami kronologis tindak pidana serta lebih mengenal pihak-pihak yang terkait dengan perkara, sehingga lebih mudah untuk menemukan proses penyelesaian yang saling menguntungkan bagi para pihak yang berperkara. Penerapan diversi masih ada yang belum tersentuh oleh hukum yaitu bila tindak pidana yang dilakukan anak berulang dan tindak pidana yang dilakukan anak ancaman pidananya diatas 7 tahun.

Konsep diversi sebagai alternatif penyelesaian pidana anak belum dapat diterapkan secara optimal. Keadaan tersebut terlihat dari banyaknya kasus anak yang berkonflik dengan hukum diselesaikan melalui jalur pengadilan sehingga jumlah anak yang dijatuhi pidana penjara masih mendominasi putusan hakim. Jumlah perkara anak sebagai pelaku tindak pidana yang berhasil dilakukan diversi di Kepolisian Resor Sibolga tahun 2017-2020 dapat dilihat pada Tabel 1.

Tabel 1. Jumlah Perkara Anak Sebagai Pelaku Tindak Pidana

\begin{tabular}{cccccc}
\hline No & Tahun & $\begin{array}{c}\text { Jumlah KSS } \\
\text { Anak }\end{array}$ & $\begin{array}{c}\text { Jumlah KSS } \\
\text { Diversi }\end{array}$ & Diversi & Keterangan \\
\hline 1 & 2017 & 22 & 2 & 1 Diversi gagal & Lanjut JPU \\
2 & 2018 & 33 & - & - & - \\
3 & 2019 & 21 & 3 & 2 Diversi gagal & Lanjut JPU \\
4 & 2020 & 23 & 3 & 1 Diversi gagal & Lanjut JPU \\
\hline
\end{tabular}

Sumber: Kepolisian Resor Sibolga, 2021

Berdasarkan Tabel 1 dapat dilihat bahwa jumlah kasus anak mengalami penurunan dari tahun 2018 sampai tahun 2020, tetapi jumlah kasus yang masuk dalam proses diversi sebanyak 2 kasus pada tahun 2017, 3 kasus pada tahun 2019 dan 2020, tetapi tidak semua proses diversi berhasil tetapai masih mengalami kegagalan dan lanjut ke Jaksa Penuntut Umum. Kepolisian Resor (Polres) Sibolga merupakan institusi penegak hukum di Wilayah Kota Sibolga. Kepolisian tersebut telah banyak menangani kasus anak yang melakukan tindak pidana, tetapi dari pengamatan penulis bahwa konsep diversi sebagai alternatif penyelesaian pidana anak belum dapat diterapkan secara maksimal. Keadaan tersebut terlihat dari banyaknya kasus anak yang melakukan tindak pidana diselesaikan melalui jalur pengadilan sehingga jumlah anak yang dijatuhi pidana penjara masih mendominasi putusan hakim.

Hasil penelitian Wahyudhi (2015) menunjukkan bahwa penanganan perkara anak harus dilakukan oleh pejabat yang memang memahami masalah anak. Dalam Undang-Undang Nomor 11 Tahun 2012 tentang Sistem Peradilan Pidana Anak. Perlindungan terhadap anak yang berhadapan dengan hukum mengalami kemajuan adanya perubahan paradigma dalam menangani perkara anak yang berhadapan dengan hukum, proses penyelesaian perkara anak tidak hanya dapat diselesaikan melalui proses peradilan akan tetapi juga dapat diselesaikan di luar proses peradilan melalui diversi dengan pendekatan keadilan restoratif dengan melibatkan semua pihak baik pelaku, korban dan saksi dengan pihak yang terkait lainnya untuk duduk bersama mencari solusi penyelesaian perkara anak demi kepentingan terbaik bagi anak.

Sedangkan hasil penelitian Rio (2016) menunjukkan bahwa anak merupakan amanah dan karunia Tuhan Yang Maha Esa yang memiliki harkat dan martabat sebagai manusia seutuhnya. Dalam Pasal 1 Angka 3 Undang-undang Nomor 11 Tahun 2012 Tentang Sistem Peradilan Pidana Anak, anak yang berkonflik dengan hukum adalah anak yang telah berumur 12 (dua belas) tahun, tetapi belum berumur 18 (delapan belas) tahun yang diduga melakukan tindak pidana. Kedudukan anak sebagai generasi muda yang meneruskan cita-cita luhur bangsa, calon-calon pemimpin bangsa dimasa mendatang dan sebagai sumber harapan generasi terdahulu, perlu mendapat 
kesempatan seluas-luasnya untuk tumbuh dan berkembang dengan wajar baik secara rohani, jasmani, dan sosial. Perlindungan anak merupakan usaha dan kegiatan seluruh lapisan masyarakat dalam berbagai kedudukan dan peranan, yang menyadari betul pentingnya anak bagi nusa dan bangsa dikemudian hari. Jika mereka telah matang pertumbuhan fisik maupun mental dan sosialnya, maka tiba saatnya menggantikan generasi terdahulu.

Penelitian ini bertujuan: Untuk mengkaji dan menganalisis aturan hukum dalam penerapan diversi terhadap anak; Untuk mengkaji dan menganalisis faktor penyebab terjadinya tindak pidana pencurian kenderaan bermotor oleh anak; Untuk mengkaji dan menganalisis kebijakan diversi terhadap tersangka anak dalam tindak pidana pencurian kenderaan bermotor pada Kepolisian Resor Sibolga.

\section{METODE PENELITIAN}

Jenis penelitian yang dipergunakan dalam penelitian ini adalah metode penelitian yuridis normatif bersifat deskriptif analisis, yaitu penelitian yang dilakukan dengan cara meneliti bahan pustaka (data sekunder) atau penelitian hukum perpustakaan (Soekanto, 2005). Penelitian hukum normatif merupakan suatu prosedur penelitian ilmiah untuk menemukan kebenaran berdasarkan logika keilmuan hukum dari sisi normatifnya (Ibrahim, 2006). Logika keilmuan yang sering dalam penelitian hukum normatif yaitu ilmu hukum yang objeknya hukum itu sendiri. Penelitian hukum normatif atau doktriner yang diajukan dalam kajian ini adalah penelitian terhadap asas-asas hukum dan sinkronisasi hukum (Zulyadi, 2020).

Metode penelitian sangat penting dalam menganalisa sebuah penelitian. Metode penelitian yang digunakan dalam penelitian ini adalah pendekatan pustaka dengan metode pendekatan kasus (case approach) dan perundang-undangan (statute approach) yaitu dilakukan dengan menelaah ketentuan perundang-undangan yang berlaku dalam kasus tersebut (Ediwarman, 2016).

Penelitian ini sangat bertumpu pada sumber data sekunder yang terdiri dari Peraturan perundangan hukum pidana positif di Indonesia yaitu KUHP, Peraturan perundangan di luar KUHP yang berkaitan dengan permasalahan, Konsep KUHP Nasional tahun 2008, Sistem Peradilan Pidana Anak, berbagai peraturan perundangan yang diperoleh dari berbagai negara sebagai bahan perbandingan serta berbagai hasil pemikiran para ahli hukum yang erat kaitannya dengan penelitian ini. Alat pengumpulan data dalam penelitina ini adalah: Wawancara langsung dengan pihak yang bertanggung jawab dan terkait langsung dalam pemeriksaan perkara tindak pidana anak, agar diperoleh gambaran mengenai proses pemeriksaan. Studi dokumentasi yaitu pengumpulan data yang diperoleh dari dokumen-dokumen internal yang terkait dengan lingkup penelitian ini.

Langkah-langkah yang ditempuh dalam penelitian ini terdiri dari 2 (dua) tahapan, meliputi: Tahapan penelitian survei di lapangan, sebagai langkah awal dilakukan dengan penentuan responden dan pengumpulan data primer. Pengumpulan data primer dengan cara wawancara berdasarkan pedoman wawancara yang telah disusun dan disiapkan sebelumnya. Kemudian dilakukan juga pengumpulan data sekunder yang ada pada lembaga hukum yang berkaitan dengan penelitian ini. Tahapan penelitian kepustakaan, penelitian ini dilakukan untuk memperoleh data sekunder yang meliputi bahan hukum primer, bahan hukum sekunder, dan bahan hukum tertier. Data yang diperoleh digunakan sebagai dasar teori untuk menganalisis data primer yang diperoleh dari penelitian lapangan. Penelitian ini sangat bertumpu pada sumber data sekunder yang terdiri dari Peraturan perundangan hukum pidana di Indonesia yaitu KUHP, Peraturan perundangan diluar KUHP yang berkaitan dengan permasalahan, Konsep KUHP Nasional tahun 2008, Sistem Peradilan Pidana Anak.

Analisis data dalam penelitian ini adalah secara kualitatif. Data sekunder yang diperoleh dari hasil penelitian yang disusun sedemikian rupa demikian analisis secara deskriptif, logis dan sistematis, yang dinyatakan oleh pihak terkait secara lisan dan dituangkan secara tertulis, serta dikaitkan bahan hukum sekunder dengan menggunakan metode deduktif dan indukatif yang 
berpedoman pada hukum pidana dan perundang-undangan yang berhubungan dengan permasalahan yang diteliti untuk menjawab permasalahannya.

Deskriptif artinya, data yang diperoleh dari lapangan yang digambarkan sesuai dengan kenyataan sebenarnya. Logis artinya dalam melakukan analisis, yang dianalisis adalah (rasionalitas) dan ilmu pengetahuan. Sistematis artinya, setiap hal-hal yang dianalisis harus tersusun dengan urutan dan berkaitan sehingga mendapatkan hasil yang diinginkan.

Penarikan kesimpulan dilakukan dengan menggunakan metode induktif. Metode induktif artinya, dari data yang bersifat khusus yang diperoleh dari penelitian penanganan diversi anak dalam tindak pidana tersangka dalam pencurian kenderaan bermotor dan ditarik kesimpulan yang bersifat umum.

\section{HASIL DAN PEMBAHASAN}

\section{Penerapan Diversi Terhadap Anak Menurut Undang-Undang No 11 Tahun 2012 tentang Sistem Peradilan Pidana Anak}

Undang-Undang sistem peradilan pidana anak ini juga sudah tercantum semua hak-hak anak dari tahap penyelidikan sampai dengan tahap pembimbingan setelah menjalani pidana. Upaya yang di berikan untuk melindungi anak di berikan dalam bentuk hak-hak yang dalam undangundang ini termuat pada Pasal 3 dan Pasal 4. Pasal 3 Setiap Anak dalam proses peradilan pidana berhak: (a) diperlakukan secara manusiawi dengan memperhatikan kebutuhan sesuai dengan umurnya; (b) dipisahkan dari orang dewasa; (c) memperoleh bantuan hukum dan bantuan lain secara efektif; (d) melakukan kegiatan rekreasional; (e) bebas dari penyiksaan, penghukuman atau perlakuan lain yang kejam, tidak manusiawi, serta merendahkan derajat dan martabatnya; (f) tidak dijatuhi pidana mati atau pidana seumur hidup; (g) tidak ditangkap, ditahan, atau dipenjara, kecuali sebagai upaya terakhir dan dalam waktu yang paling singkat; $(\mathrm{h})$ memperoleh keadilan di muka pengadilan Anak yang objektif, tidak memihak, dan dalam sidang yang tertutup untuk umum; (i) tidak dipublikasikan identitasnya; (j) memperoleh pendampingan orang tua/Wali dan orang yang dipercaya oleh anak; (k) memperoleh advokasi sosial; (l) memperoleh kehidupan pribadi; (m) memperoleh aksesibilitas, terutama bagi anak cacat; (n) memperoleh pendidikan; (o) memperoleh pelayananan kesehatan; dan (p) memperoleh hak lain sesuai dengan ketentuan peraturan perundang-undangan.

Pasal 4: (1) Anak yang sedang menjalani masa pidana berhak: (a) mendapat pengurangan masa pidana; (b) memperoleh asimilasi; (c) memperoleh cuti mengunjungi keluarga; (d) memperoleh pembebasan bersyarat; (e) memperoleh cuti menjelang bebas; (f) memperoleh cuti bersyarat; dan (g) memperoleh hak lain sesuai dengan ketentuan peraturan perundang-undangan. (2) Hak sebagaimana dimaksud pada Ayat (1) diberikan kepada Anak yang memenuhi persyaratan sebagaimana diatur dalam ketentuan peraturan perundang-undangan.

Undang-Undang mengamanatkan adanya upaya diversi dalam sistem peradilan anak. Oleh karena itu hakim yang diminta oleh Undang-Undang Nomor 11 Tahun 2012 tentang Sistem Peradilan Pidana Anak lebih memahami segala hal ikhwal anak, agar tidak begitu saja menjatuhkan pidana penjara yang di dalam aturan positif Indonesia adalah sebagai upaya yang terakhir. Beberapa ketentuan mengenai diversi adalah: (1) Pasal 6 Undang-Undang Nomor 11 Tahun 2012 menyebutkan tujuan Diversi yaitu: (a) Mencapai perdamaian antara korban dan Anak; (b) Menyelesaikan perkara Anak di luar proses peradilan; (c) Menghindari Anak dari perampasan kemerdekaan; (d) Mendorong masyarakat untuk berpartisipasi; dan (e) Menanam rasa tanggung jawab kepada Anak.

Diberlakukannya Undang-Undang Nomor 11 Tahun 2012 tentang Sistem Peradilan Pidana Anak maka terdapat ketentuan lex specialis terhadap tugas dan wewenang kepolisian, kejaksaan dan hakim. Salah satu yang khas dan membedakan adalah bentuk diversi. Pada tingkat penyidikan, penuntutan, dan pemeriksaan perkara anak di Pengadilan Negeri wajib di upayakan diversi oleh aparat penegak hukum. Diversi sebagaimana dimaksud dilaksanakan dalam hal tindak pidana yang dilakukan diancam dengan pidana penjara dibawah 7 (tujuh) tahun dan bukan merupakan pengulangan tindak pidana (Pasal 7 ayat (1) dan (2) Undang-Undang Nomor 11 Tahun 2012 tentang Sistem Peradilan Pidana Anak). 
Pasal 8 Undang-Undang Nomor 11 Tahun 2012 mengatur mengenai diversi, yaitu (a) Proses Diversi dilakukan melalui musyawarah dengan melibatkan Anak dan orangtua/walinya, korban dan/atau orangtua/Walinya, Pembimbing Kemasyarakatan, dan Pekerja Sosial Profesional berdasarkan pendekatan Keadilan Restoratif. (b) Dalam hal diperlukan, musyawarah sebagaimana dimaksud pada ayat (1) dapat melibatkan Tenaga Kesejahteraan Sosial, dan/atau masyarakat. (c) Proses diversi wajib memperhatikan: kepentingan korban, kesejahteraan dan tanggung jawab Anak, penghindaran stigma negatif, penghindaran pembalasan, keharmonisan masyarakat, dan kepatutan, kesusilaan, dan ketertiban umum.

Pasal 9 ayat (1) Undang-Undang Nomor 11 Tahun 2012 menyebutkan: (1) Penyidik, Penuntut Umum dan Hakim dalam melakukan Diversi harus mempertimbangkan: (a) Kategori tindak pidana; (b) Umur Anak; (c) Hasil penelitian kemasyarakatan dari Bapas, dan; (d) Dukungan lingkungan keluarga dan masyarakat.

Proses peradilan pidana Anak dilanjutkan dalam hal proses diversi, jika tidak dapat menghasilkan kesepakatan maka diversi tidak dilaksanakan. Oleh karena itu maka akan diberlakukan hukum formil yang tunduk pada Undang-Undang Nomor 11 Tahun 2012 tentang Sistem Peradilan Pidana Anak dalam persidangan.

\section{Faktor Penyebab Terjadinya Tindak Pidana Pencurian Kenderaan Bermotor Oleh Anak}

Pencurian kenderaan bermotor sering terjadi di masyarakat, sehingga cukup meresahkan masyarakat pemilik kenderaan bermotor. Berbagai upaya yang dilakukan oleh pemilik kenderaan bermotor untuk melakukan pengamanan sering tidak berhasil karena pelaku pencurian sudah memiliki keahlian yang cukup baik untuk membuka berbagai jenis kunci pengaman yang dipasang dalam sepeda motor.

Pelaku pencurian kenderaan bermotor tidak hanya melibatkan orang dewasa, tetapi juga melibatkan anak-anak di bawah umur. Keterlibatan anak di bawah umur dalam melakukan aksi pencurian kenderaan bermotor sudah sangat sering terjadi, bahkan beberapa diantaranya bernasib naas karena mendapat perlakuan keras dari massa. Ada banyak kejadian anak sebagai pelaku pencurian kenderaan bermotor dihakimi oleh massa, sehingga menyebabkan anak tersebut mengalami luka berat bahkan ada yang sampai meninggal dunia. Anak sebagai pelaku tindak pidana pada dasarnya tidaklah didasari oleh pemahaman yang kuat terhadap sebab akibat dari tindak pidana yang dilakukannya, sehingga sebenarnya anak sebagai pelaku tidak dapat dengan mudah dipersalahkan.

Keterlibatan akan dalam pencurian sepeda motor tentu saja memiliki latar belakang tersendiri, dan sebagian besar bukan karena faktor yang terdapat di dalam dirinya, tetapi karena faktor yang terdapat diluar dirinya sendiri.

Faktor Intern, Faktor Ekonomi, Anak sebagai pelaku pencurian kenderaan bermotor biasanya berasal dari golongan kelkuarga ekonomi lemah, sehingga merasa kekurangan atas kebutuhan hidupnya. Anak sebagai pelaku pencurian kenderaan bermotor didorong oleh faktor keinginan untuk mendapatkan material yang lebih baik, karena keluarganya kurang mampu memenuhi kebutuhannya secara lebih memadai. Padahal terdapat banyak godaan dari lingkungan untuk melakukan konsumsi atas berbagai kebutuhan anak. Orang tua yang kurang berpenghasilan relatif kurang mampu memenuhi keinginan anak yang biasanya menggebu-gebu terhadap perolehan barang atau jasa lainnya yang semakin banyak digandrungi oleh anak-anak.

Kurangnya Pengawasan Orang Tua. Pengawasan orang tua menjadi faktor yang paling penting mengendalikan anak-anak dari perilaku kejahatan. Jika pengawasan orang tua lemah maka anak-anak akan mudah terjerumus terhadap hal-hal yang tidak baik di lingkungannya. Kesibukan orang tua dengan pekerjaannya sering menyebabkannya lupa terhadap anak-anaknya, sehingga tidak melakukan pengawasan yang memadai terhadap perilaku anak-anaknya. Anak-anak menjadi lebih bebas di luar rumah, dan bahkan sebagian besar waktunya berada di luar rumah, sehingga sangat mudah terpengaruh dengan lingkungan jahat. Banyak orang tua tidak mengetahui bahwa anaknya telah terlibat dalam tindak kejahatan pencurian kenderaan bermotor, karena orang tua tersebut sangat jarang berada di rumah. Orang tua baru mengetahui keterlibatan anaknya dalam 
tindak kejahatan setelah anaknya tertangkap oleh aparat penegak hukum karena melakukan tindak kejahatan pencurian sepeda motor.

Kurangnya Kesadaran Hukum Oleh Anak. Anak-anak tentu masih belum cakap secara hukum, artinya belum mengetahui sebab akibat dari segala perbuatannya, khususnya dihadapan hukum. Faktor kurangnya kesadaran hukum oleh anak tentu dapat dipahami karena masih di bawah umur sehingga sering sangat mudah untuk melakukan tindak kejahatan. Faktor pendorong terjadinya pencurian kenderaan bermotor oleh anak juga disebabkan kurangnya pemahamannya terhadap hukum. Anak-anak tidak menyadari sepenuhnya akibat hukumnya jika anak melakukan pencurian terhadap sepeda motor orang lain, sehingga dia menjadi lebih mudah bertindak melakukan pencurian demi mendapatkan uang yang banyak. Anak-anak hanya mengetahui bahwa mencuri itu salah, tetapi tidak mengetahui apa akibat hukum yang akan diterimanya atau dipertanggungjawabkannya jika berhadapan dengan hukum atas pencurian sepeda motor.

Kebutuhan Narkotika. Anak-anak yang berada di lingkungan luar keluarga tentu menjadi sangat riskan terlibat dalam berbagai jenis tindak pidana seperti tindak pidana narkotika. Banyak anak-anak yang pada akhirnya terlibat sebagai penyalahguna narkotika, sehingga menjadi pecandu. Tingkat kecanduan terhadap narkotika dapat mendorong anak untuk memperoleh uang untuk membeli narkotika dengan melakukan pencurian kenderaan bermotor. Faktor keterlibatan anak sebagai pecandu narkotika telah menjadi faktor pendorong dalam melakukan tindak pidana narkotika. Banyak anak yang terlibat sebagai pecandu dalam jaringan narkotika akhirnya secara terpaksa harus melakukan tindak pidana pencurian kenderaan bermotor, demi memperoleh uang dengan cepat untuk membeli narkotika yang menjadi kebutuhannya. Dalam hal ini kenderaan bermotor menjadi sasaran yang dianggap dapat ditemukan dengan cepat menjadi sasaran pencurian, karena kenderaan bermotor biasanya sangat banyak terparkir di jalanan atau pun di tempat parkir (Kurniawan, 2008).

Faktor Ekstern, Adanya Kesempatan. Adanya kesempatan untuk melakukan tindak kejahatan dapat mendorong anak untuk melakukannya terutama anak-anak yang sudah terbiasa dalam tindak criminal. Adanya kesempatan menjadi faktor yang mendorong terjadinya pencurian kenderaan bermotor. Misalnya jika kenderaan diletakkan pada tempat-tempat yang sepi, maka pelaku terutama anak-anak yang sudah sering terlibat dalam aksi kejahatan akan segera melakukan aksinya melakukan pencurian sepeda motor. Banyak anggota masyarakat yang kurang waspada dengan pencurian sepeda motor sehingga menjadi sasaran bagi anak-anak yang berada alam kelompok criminal. Seharusnya masyarakat mempunyai tindakan pencegahan bagi sepeda motornya agar tidak memberi kesempatan bagi orang lain melakukan pencurian terhadap sepeda motornya.

Adanya Pengaruh Lingkungan. Anak-anak sangat mudah terpengaruh oleh lingkungannya, terutama jika sudah terhubung dengan kelompok criminal dan geng motor. Kelompok criminal dang eng motor merupakan pelaku yang sering terlibat dalam aksi pencurian kenderaan bermotor. Lingkungan pergaulan anak-anak juga menjadi faktor pendorong anak untuk melakukan pencurian sepeda motor. Itu disebabkan lingkungan pergaulan sangat mudah mempengaruhi anak-anak, terlebih anak-anak pada dasarnya tidak memahami tindakan yang dilakukan jika melakukan pelanggarant terhadap hukum. Hal ini disebabkan banyak anak-anak yang kurang perhatian dari orang tua, sehingga menjadi terbebas untuk mencari lingkungan pergaulan sendiri, seperti lingkungan geng motor atau bahkan terlibat dalam pergaulan lingkungan kelompok criminal. Anak-anak yang bebas berkeliaran biasanya akan cepat akrap dengan lingkungan yang tidak terkendali atau lingkungan yang merupakan kelompok pelaku criminal terutama kelompok pencurian sepeda motor.

Dipengaruhi Oleh Orang Dewasa. Orang dewasa dapat memanfaatkan anak-anak untuk membantunya melakukan tindak pidana pencurian kenderaan bermotor, dengan janji akan diberikan uang dalam jumlah besar. Orang dewasa dapat menggunakan kelicikannya memanfaatkan anak yang kemampuan berpikirnya masih rendah, untuk melakukan pencurian kenderaan bermotor. Orang dewasa ini biasanya akan menjanjikan upah yang besar kepada anak jika berhasil membawa sepeda motor yang dimaksud, sehingga dengan cepat akan menjadi tergiur untuk melakukan permintaan orang dewasa yang menyuruhnya. Hal ini tentu menjadi kesalahan 1228 http://mahesainstitute.web.id/ojs2/index.php/jehss mahesainstitut@gmail.com 1228

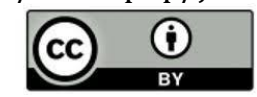


dari orang tua, karena kurang melakukan pengawasan terhadap anaknya yang masih dibawah umur, sehingga menjadi lebih mudah dimanfaatkan oleh orang lain untuk kepentingannya.

Banyak Penadah Sepeda Motor. Ketersediaan penadah sepeda motor juga turut mendorong terjadinya pencurian sepeda motor oleh anak. Jika anak mudah mendapatkan penadah maka anak akan terdorong melakukan pencurian. Keberadaan orang yang bekerja sebagai penadah barang curian termasuk sepeda motor hasil curian akan lebih mendorong anak untuk melakukan aksi pencurian. Hal ini disebabkan anak tidak perlu berpikir terlalu panjang bagaimana menjual hasil curian tersebut, karena memang orang yang bersedia menampung hasil curian telah tersedia. Kemudahan untuk memperoleh uang dengan cepat dari penadah akan semakin mendorong pelaku untuk melakukan pencurian, karena terdapat kepastian bahwa sepeda motor hasil curiannya akan segera laku dan segera dicincang hingga tidak meninggalkan jejak penyidikan bagi kepolisian.

\section{Kebijakan Diversi Terhadap Tersangka Anak Dalam Tindak Pidana Pencurian Kenderaan Bermotor Pada Kepolisian Resor Sibolga}

Diversi dalam UU No. 11 Tahun 2012 tentang Sistem Peradilan Pidana Anak (SPPA) diatur pada pasal 6 sampai pasal 15, sedangkan peran penyidik Polri dalam upaya diversi diatur dalam pasal 29. Secara garis besar maka pada UU SPPA diatur mengenai upaya dan persyaratan diversi, proses diversi, serta penetapan dan pelaksanaan hasil kesepakatan diversi.

Pada pasal 7 ayat (1) dinyatakan bahwa pada pada tingkat penyidikan, penuntutan, dan pemeriksaan perkara di pengadilan negeri wajib diupayakan diversi. Dengan demikian upaya diversi terhadap anak pelaku pencurian kenderaan bermotor telah wajib diupayakan pada tahap penyidikan di kepolisian. Pelaksanaan diversi di kepolisian akan lebih menjamin perlindungan terhadap anak karena tersangka anak akan terhindar dari tahap penuntutan dan pemeriksaan perkara di pengadilan yang dapat mengganggu masa depan anak. Kebijakan yang dilakukan oleh pihak kepolisian adalah secara formal dan non formal.

Kebijakan Formal. Untuk mengetahui bagaimana kebijakan formal diversi terhadap anak yang melakukan pencurian kenderaan bermotor pada Kepolisian Resor Sibolga maka penulis telah melakukan wawancara dengan berbagai pihak yang berkompetan, sebagaimana diuraikan berikut ini. Persyaratan Diversi. Penyidik harus segera mengupayakan diversi dengan memperhatikan berbagai persyaratan yang diatur dalam undang-undang SPPA. Sesuai pasal 29 ayat (1) bahwa penyidik kepolisian wajib mengupayakan diversi paling lama 7 hari setelah penyidikan dimulai. Adapun persyaratannya ditetapkan pada pasal 7 ayat (2) yaitu ancaman tindak pidana dibawah 7 tahun dan bukan merupakan pengulangan tindak pidana. Penyidik anak di Kepolisian Resort Sibolga telah lebih mengutamakan penyelesaian perkara anak sebagai tersangka pencurian sepeda motor di luar pengadilan melalui diversi. Setiap laporan atas perkara pencurian sepeda motor oleh anak akan ditindaklanjuti sesuai dengan undang-undang yang berlaku, dimana upaya diversi menjadi pilihan utama dalam penyelesaiannya, karena ancaman pidanana kurang dari 7 tahun, dengan syarat bahwa anak tersebut belum pernah terlibat dalam tindak pidana.

Menurut undang-undang SPPA bahwa kebijakan diversi harus diupayakan paling lama 7 hari setelah dimulainya penyidikan. Hal tersebut dimaksudkan untuk lebih menjamin penyelesaian yang cepat terhadap perkara anak sehingga tidak mengganggu perkembangan mental anak. Kepolisian di Kepolisian Resort Sibolga telah berupaya dengan segera menyelesaikan perkara anak pelaku pencurian kenderaan bermotor melalui diversi. Hal tersebut terlihat dari proses diversi yang telah dimulai sejak beberapa hari dari waktu pelaporan, sehingga upaya dimulainya proses diversi jarang melampaui batas waktu 7 hari dari dimulainya penyidikan sebagaimana ditetapkan dalam UU SPPA.

Persyaratan utama dalam diversi adalah ancaman pidana di bawah 7 tahun. Dalam hal ini bahwa ancaman pidana tersebut telah dikurangi setengah dari ancaman pidana bagi orang dewasa. Ancaman pidana pencurian kenderaan bermotor yang dilakukan oleh anak diancam kurang dari 7 tahun, maka hal tersebut jarang menjadi penghalang bagi kepolisian dalam mengupayakan diversi. Musyawarah diversi akan segera dilakukan jika korban pencurian tidak keberatan dengan upaya diversi yang akan dilakukan. 
Persyaratan kedua dalam upaya diversi adalah bahwa perkara anak bukan merupakan pengulangan tindak pidana. Kepolisian dapat menerapkan persyaratan diversi sesuai dengan yang diatur dalam undang-undang. Penyelesaian perkara anak yang melakukan pencurian sepeda motor dan merupakan pengulangan tindak pidana tidak diupayakan melalui diversi, tetapi diselesaikan melalui proses peradilan pidana anak sebagaimana diatur dalam undang-undang SPPA, baik tindak pidana yang sama maupun tindak pidana yang berbeda. Artinya bahwa anak sebagai tersangka ranmor yang mengulangi tindak pidana yang sama maupun tindak pidana lain, akan diproses melalui sistem peradilan pidana, karena diversi tidak memenuhi syarat untuk dilakukan.

Pada pasal 9 UU SPPA dinyatakan bahwa kepolisian dalam melakukan diversi harus mempertimbangkan umur anak. Dalam hal ini, diversi hanya dapat dilakukan terhadap pelaku anak dan tidak dapat dilakukan terhadap pelaku orang dewasa dengan korban anak. Kepolisian belum sepenuhnya secara tegas menerapkan batas umur anak untuk diupayakan diversi, karena ternyata terdapat kasus anak sebagai pelaku ranmor dimana pelaku sudah tergolong pada umur dewasa tetapi tetap diupayakan diselesaikan di luar pengadilan. Adapun alasan pihak penyidik dalam mengupayakan diversi tersebut adalah adanya kesepakatan damai antara pihak keluarga pelaku dengan pihak keluarga korban. Tetapi sesuai dengan peraturan hukum bahwa diversi pada UU SPPA hanya dapat diberikan kepada anak. UU SPPA hanya berlaku bagi anak sebagai pelaku dan juga anak sebagai korban dan anak sebagai saksi. Sedangkan bila pelakunya adalah orang dewasa dan korbannya adalah anak, UU SPPA tidak dapat diterapkan.

Berdasarkan pasal 32 ayat (2) UU SPPA bahwa anak pelaku tindak pidana hanya dapat ditahan jika telah berumur lebih dari 14 tahun, dan anak yang diancam pidana kurang dari 7 tahun tidak dapat ditahan. Dengan demikian sesuai dengan undang-undang tersebut bahwa terhadap anak yang sedang dalam proses diversi tidak dapat dilakukan penahanan. Kepolisian telah menerapkan aturan untuk tidak menahan pelaku anak yang sedang dalam proses diversi. Walaupun pada dasarnya penahanan merupakan kewenangan kepolisian, tetapi dalam hal perkara anak sebagai pelaku ranmor, maka kepolisian mempertimbangkan adanya upaya diversi sehingga penahanan tidak dilakukan. Upaya tersebut dilakukan dengan bersikap tegas menolak keinginan korban pencurian untuk menahan anak yang melakukan tindak pidana.

Proses Diversi. Berdasarkan UU SPPA bahwa proses diversi terhadap anak tersangka pencurian kenderaan bermotor diawali dengan adanya pemberitahuan dan penawaran penyelesaian perkara di luar peradilan pidana, baik kepada keluarga anak sebagai pelaku tindak pidana maupun kepada korban. Pada tahap selanjutnya, penyidik juga harus secara aktif melakukan mediasi dengan memperhatikan kepentingan para pihak terkait. Langkah awal dari proses diversi yang dilakukan penyidik adalah menawarkan kepada para pihak keluarga anak pelaku pencurian kenderaan bermotor dan kepada pihak korban atas adanya upaya untuk menyelesaikan perkara dengan melakukan musyawarah. Melalui penawaran tersebut maka kepolisian segera dapat mengetahui kesediaan para pihak untuk memulai pembicaraan damai, yang kemudian dilanjutkan dengan penentuan waktu dan tempat pelaksanaan musyawarah. Menurut informasi bahwa inisiator diversi selalu muncul dari penyidik kepolisian sebagai upaya untuk mewujudkan perlindungan anak melalui penerapan UU SPPA.

Musyawarah harus melibatkan bebagai pihak, termasuk juga melibatkan pembimbing kemasyarakatan dan pekerja sosial profesional. Hal tersebut diatur pada UU SPPA pasal 8 bahwa dalam musyawarah diversi tidak hanya melibatkan anak dan keluarganya serta korban dan keluarnya, tetapi juga melibatkan pembimbing kemasyarakatan, pekerja sosial professional serta tokoh masyarakat. Upaya yang dilakukan oleh kepolisian untuk menghadirkan para pihak sudah dilaksanakan dengan baik, dimana penyidik tidak hanya melibatkan keluarga pihak anak pelaku ranmor dan keluarga pihak korban pencurian, tetapi juga melibatkan pembimbing masyarakat dan tokoh masyarakat di daerah penelitian. Peran dari pihak pembimbing kemasyarakatan dan tokoh masyarakat bukan hanya sebagai pendengar yang menyaksikan adanya musyawarah, tetapi juga berperan memberikan pandangan kepara para pihak agar penyelesaian masalah dapat segera ditemukan dan memuaskan semua pihak.

Penyidik mempunyai peran penting dalam mengupayakan tercapainya kesepakatan, yaitu dengan mencari titik temu antara kepentingan para pihak, sehingga kesepakatan damai dapat 123030 http://mahesainstitute.web.id/ojs2/index.php/jehss mahesainstitut@gmail.com

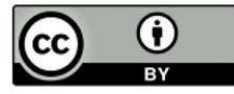


segera diwujudkan dan dapat dilaksanakan. Oleh karena itu selama proses diversi penyidik harus berperan aktif. Kepolisian sudah berupaya maksimal dalam mencari titik temu antara pihak keluarga anak pelaku ranmor dengan pihak korban pencurian, karena peran kepolisian dalam diversi tersebut juga merupakan bagian dari tugas penyidik sebagaimana diamanatkan oleh UU SPPA. Namun demikian keberhasilan musyawarah justru lebih ditentukan oleh para pihak, karena bagaimanapun peran penyidik terbatas hanya sebagai fasilisator yang berupaya mengutamakan penyelesaian perkara melalui musyawarah. Kesulitan sering terjadi manakala pihak korban ranmor meminta ganti rugi dalam jumlah yang cukup besar diluar kemampuan keluarga pelaku dalam memenuhinya, atau bisa juga karena memang pihak korban sama sekali tidak menghendaki perdamaian. Tetapi pada sisi lain, terdapat juga kemungkinan pihak keluarga anak sebagai pelaku ranmor justru tidak mempunyai itikad baik untuk memberikan ganti rugi yang layak, sehingga mengakibatkan masalah menjadi semakin meruncing.

Penetapan dan Pelaksanaan Hasil Kesepakatan Diversi. Jika musyawarah perdamaian dapat berhasil mencapai kesepakatan, maka tahap lebih lanjut adalah menuangkan kesepakatan tersebut dalam bentuk hasil kesepakatan diversi, yang kemudian ditandagangani oleh para pihak yang terkait dalam pelaksanaan musyawarah. Pada tahap selanjutnya hasil kesepakatan tersebut harus diajukan ke pengadilan negeri untuk memperoleh penetapan. Setelah ditetapkan maka hasil kesepakatan harus dilaksanakan, yang kemudian dilanjutkan dengan penghentian penyidikan perkara oleh kepolisian.

Pada pasal 12 ayat (1) UU SPPA dinyatakan bahwa hasil kesepakatan dari musyawarah harus dituangkan dalam bentuk kesepakatan diversi. Kepolisian telah membuat dokumen kesepakatan dengan baik, jelas dan rinci serta ditandatangani oleh semua pihak yang terkait dengan musyawarah. Hasil kesepakatan diversi yang jelas dan rinci tentu akan menghindarkan penafsiran yang berbeda dari pelaksana kesepakatan, sehingga pelaksanaannya juga dapat dilakukan dengan baik. Dokumen kesepakatan tersebut juga perlu ditandangani oleh semua pihak yang terkait dengan pelaksanaan musyawarah, yaitu pelaku anak dan keluarganya, korban dan keluarganya, pembimbing kemasyarakatan, tokoh masyarakat serta penyidik kepolisian. Dengan demikian semua pihak terkait tersebut merasa bertanggungjawab untuk benar-benar melaksanakan kesepakatan sesuai dengan peranannya masing-masing.

Setelah kesepakatan memperoleh penetapan dari pengadilan negeri, selanjutnya kesepakatan tersebut harus dilaksanakan. Kepolisian dalam hal ini harus aktif melakukan pengawasan terhadap pelaksanaan kesepakatan diversi sebagaimana dinyatakan pada pasal 14 ayat (1) UU SPPA. Sebagai pengawas maka kepolisian harus melakukan pemantauan terhadap proses pelaksanaan kesepakatan sampai kesepakatan tersebut benar-benar telah dilaksanakan sebagaimana mestinya untuk mengembalikan korban tindak pidana pada keadaan semula sebagaimana dimaksud dengan keadilan restoratif. Penyidik kepolisian telah melakukan pemantauan dengan baik terhadap pelaksanaan kesepakatan diversi. Hal tersebut disebabkan secara prosedur bahwa tindakan lebih lanjut terhadap penanganan perkara hanya dapat diputuskan setelah memperoleh informasi secara jelas bagaimana tingkat keberhasilan pelaksanaan kesepakatan diversi.

Selanjutnya, terdapat juga kemungkinan bahwa kesepakatan diversi tidak dapat dilaksanakan di lapangan karena berbagai kendala, atau karena adanya perubahan pendirian dari salah satu pihak yang terkait dengan perkara anak. Menurut pasal 13 huruf b, proses peradilan pidana terhadap perkara anak harus dilanjutkan jika kesepakatan diversi tidak benar-benar dilaksanakan oleh para pihak. Kemungkinan tidak terlaksananya kesepakatan diversi dapat disebabkan keluarga pelaku tidak bersedia memberikan ganti rugi sebagaimana telah ditetapkan. Jika kesepakatan diversi tidak dilaksanakan maka kepolisian akan mengambil tindakan tegas untuk melanjutkan penyelesaian perkara melalui proses peradilan pidana dengan melimbahkan berkas perkara ke penuntut umum.

Kebijakan Non Formal, Kebijakan non formal yang dilakukan dalam diversi ini adalah pihak kepolisian meminta korban dan tersangka untuk berdamai tanpa melibatkan penegak hukum terlibat dalam penyelesaian masalah yang ada, yaitu dengan memanggil tokoh masyarakat, 
tetangga dan pihak lain yang dianggap relevan dengan penyelesaian perkara dengan cara musyawarah. Kepolisian menerapkan kebijakan non formal dengan meminta kedua belah pihak baik korban maupun pelaku untuk menyelesaikan masalahnya secara musyawarah tanpa melibatkan aparat penegak hukum, sehingga penyelesaiannya dapat segera mencapai hasil dan dengan biaya yang paling efisien. Hal ini disebabkan pada umumnya masyarakat memiliki mekanisme tersendiri yang sifatnya non formal untuk menyelesaikan berbagai perkara yang terjadi antara anggota masyarakat tanpa membuat laporan kepada kepolisian (Batu, Dkk, 2020).

\section{SIMPULAN}

Aturan hukum dalam penerapan diversi terhadap anak yang melakukan tindak pidana yang diatur pada peraturan sebagai berikut: Undang-undang No .11 Tahun 2012 tentang Sistem Peradilan Pidana Anak, yaitu pada pasal 6 - pasal 15. Ketentuan yang diatur adalah adanya kewajiban penyidik kepolisian untuk mengupayakan diversi terhadap tindak pidana yang dilakukan oleh anak dengan persyaratan ancaman pidana penjara tidak melebihi 7 tahun dan bukan merupakan pengulangan tindak pidana. Undang-undang No. 35 Tahun 2014 Tentang Perlindungan Anak, yaitu pasal 1 angka (2). Perlindungan anak adalah segala kegiatan untuk menjamin dan melindungi anak dan hak-haknya agar dapat hidup, tumbuh, berkembang, dan berpartisipasi, secara optimal sesuai dengan harkat dan martabat kemanusiaan, serta mendapat perlindungan dari kekerasan dan diskriminasi. Faktor penyebab terjadinya tindak pidana pencurian kenderaan bermotor oleh anak adalah sebagai berikut: Faktor intern terdiri dari faktor ekonomi dimana anak berasal dari keluarga golongan ekonomi lemah, kurangnya pengawasan orang tua karena sibuk dalam pekerjaan, kurangnya kesadaran hukum oleh anak karena masih kurang matang dalam berpikir, kebutuhan narkotika karena sudah salah dalam pergaulan teman. Faktor ekstern terdiri dari faktor adanya kesempatan melakukan pencurian, adanya pengaruh lingkungan dimana anak terhubung dengan kelompok kriminal ataupun geng motor, adanya pengaruh orang dewasa yang berupaya memanfaatkan anak-anak untuk melakukan pencurian kenderaan bermotor, dan banyaknya penadah kenderaan bermotor hasil curian. Kebijakan diversi terhadap tersangka anak dalam tindak pidana pencurian kenderaan bermotor pada Kepolisian Resor Sibolga dilakukan dengan cara: Kebijakan formal terdiri dari Kepolisian memulai diversi paling lama 7 hari setelah penyidikan dimulai dengan melibatkan pihak keluarga anak, keluarga korban, pembimbing kemasyarakatan, dan tokoh masyarakat. Penerapan diversi tetap memperhatikan ketentuan yang ditetapkan dalam UU SPPA, termasuk juga persyaratan diversi serta mempertimbangkan kepentingan korban. Disamping itu, kepolisian juga mengawasi pelaksanaan kesepakatan diversi hingga benar-benar terlaksana dimana korban menerima ganti rugi sebesar yang telah disepakati. Kebijakan non formal yang dilakukan kepolisian adalah pihak kepolisian meminta korban dan tersangka untuk berdamai tanpa melibatkan penegak hukum terlibat dalam penyelesaian masalah yang ada, yaitu dengan memanggil tokoh masyarakat, tetangga dan pihak lain yang dianggap relevan dengan penyelesaian perkara dengan cara musyawarah.

\section{DAFTAR PUSTAKA}

Batu, F.L., Siregar, T. \& Muazzul. (2020). Peranan Kepolisian Dalam Memberantas Tindak Pidana Pencurian Dengan Kekerasan Di Wilayah Patumbak (Studi Kasus Di Polsek Patumbak). JUNCTO, 2(1) 2020: 68-77

Djamil, M. N. (2012). Anak Bukan Untuk Di Hukum. Jakarta: Sinar Grafika.

Ediwarman. (2016). Monograf Metode Penelitian Hukum (Panduan Penulisan Skripsi, Tesis, dan Disertasi). Medan: Genta Publishing.

Gosita, A. (2003). Masalah Korban Kejahatan. Jakarta: Akademindo Pressindo.

Gultom, M. (2012). Perlindungan Hukum terhadap Anak dan Perempuan. Medan: Aditama.

Ibrahim, J. (2006). Teori Dan Metedologi Penelitian Hukum Normatif. Jakarta: Pustaka Pelajar.

Kurniawan. (2008). Definisi dan Pengertian Narkotika Dan Golongan/Jenis Narkotika Sebagai Zat Terlarang. Jakarta: Bina Aksara8.

Marlina. (2008). Penerapan Konsep Diversi Terhadap Anak Pelaku Tindak Pidana Dalam Sistem Peradilan Pidana Anak. Jurnal Equality, 13(1).

12.230 http://mahesainstitute.web.id/ojs2/index.php/jehss mahesainstitut@gmail.com

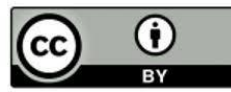


Marlina. (2010). Pengantar Konsep Diversi dan Restorative Justice dalam Hukum Pidana. Medan: USU Press. Muladi. (2012). Hak Asasi Manusia, Politik dan Sistem Peradilan Pidana. Semarang: BP Undip.

Prints, D. (2002). Hukum Anak Indonesia. Bandung: Citra Aditya Bakti.

Rahardjo, S. (2005). Permasalahan Hukum di Indonesia. Bandung: Alumni.

Reksodiputro, M. (2014). Sistem Peradilan Pidana (Peran Penegak Hukum Melawan Kejahatan), Pusat Pelayanan Keadilan dan Pengabdian Hukum. Jakarta: Universitas Indonesia.

Rio, S, (2015). Pelaksanaan Hak-hak Anak yang Berkonflik dengan Hukum pada Tahap Penyidikan Menurut Undang-undang Nomor 11 Tahun 2012 tentang Sistem Peradilan Pidana Anak (Studi pada Polrestas Padang), Skripsi tidak diterbitkan. Padang: Universitas Andalas.

Soekanto, S. (1998). Pengantar Penelitian Hukum. Jakarta: Universitas Indonesia Press.

Wahyudhi, D. (2015). Perlindungan terhadap Anak yang Berhadapan dengan Hukum Melalui Pendekatan Restorative Justice. Jurnal Ilmu Hukum, 143-163.

Zulyadi, R. (2020). Kerangka Teori Dalam Penelitian Hukum. Medan: Enam Media.

Undang-Undang No.36 Tahun 2009 Tentang Kesehatan.

Undang-Undang No.4 Tahun 1979 Tentang Kesejahteraan Anak.

Undang-Undang No.39 Tahun 1999 Tentang Hak Asasi Manusia.

Undang-Undang Nomor 11 Tahun 2012 Tentang Sistem Pidana Peradilan Anak.

Undang-Undang Nomor 35 Tahun 2014 Tentang Perlindungan Anak.

Kitab Undang-Undang Hukum Pidana (KUHP). 